\title{
Supply management capabilities, routine bundles and their impact on firm performance
}

\begin{abstract}
Despite the generally positive contribution of supply management capabilities to firm performance their respective routines require more depth of assessment. Using the resourcebased view we examine four routines bundles comprising ostensive and performative aspects of supply management capability - supply management integration, coordinated sourcing, collaboration management and performance assessment. Using structural equation modelling we measure supply management capability empirically as a second-order latent variable and estimate its effect on a series of financial and operational performance measures. The routines-based approach allows us to demonstrate a different, more fine-grained approach for assessing consistent bundles of homogeneous patterns of activity across firms. The results suggest supply management capability is formed of internally consistent routine bundles, which are significantly related to financial performance, mediated by operational performance. Our results confirm an indirect effect of firm performance for 'core' routines forming the architecture of a supply management capability. Supply management capability primarily improves the operational performance of the business, which is subsequently translated into improved financial performance. The study is significant for practice as it offers a different view about the face-valid rationale of supply management directly influencing firm financial performance. We confound this assumption, prompting caution when placing too much importance on directly assessing supply management capability using financial performance of the business.
\end{abstract}

Keywords: Resource-based view; Supply management capability; Routines; Structural equation modelling 


\section{Introduction}

The field of operations management increasingly uses the resource-based view (RBV) to explain how strategically managed interactions with suppliers contribute to competitive advantage (e.g., Hult et al., 2003; Chen et al., 2004; McIvor, 2009; Cao and Zhang, 2010; Allred et al., 2011; Squire et al, 2011). These studies share a core proposition of the RBV that firms augment their resource endowments by co-developing capabilities with suppliers, as well as engaging in sourcing.

This study contributes differently to the existing stream of studies of supply management grounded in the RBV, most of which explore the pivotal role of dynamic capabilities between firms to develop what Helfat et al. (2007) term "evolutionary fitness" - a learning process by which firms change the way they use their resource base. Chen et al. (2004) identify a longterm orientation, limited numbers of key suppliers, and communication as key routines which contribute to the building of supply management capability.

Despite the generally positive contributions identified for capability development between firms there is little detailed attention paid to empirically testing internal supply management routines. Das and Narasimhan (2000), Chen et al. (2004), and Lawson et al. (2009) argue that a more comprehensive understanding of internal as well as inter-firm supply management capabilities is required, whilst González-Benito (2007) and Narasimhan et al. (2001) conclude that alternative conceptual approaches should be explored to fully understand the detailed nature of firm capabilities. As research using a routines-based approach is still embryonic we seek to encourage research along two lines of inquiry: (1) How can routine supply management capabilities be conceptualised so repetitive organizational actions be 
separated from idiosyncratic practices? and (2) How do supply management routines and capabilities contribute to firm performance?

Helfat and Peteraf (2003), Winter (2003), and Zahra et al. (2006) note that firms must be technically fit to leverage "here and now" opportunities. If current capabilities for product or service delivery are mediocre then less of an advantage accrues. Prior research indicates carefully developed routines increase revenue (Peng and York, 2001), reduce the cost of providing services to customers (Kaleka, 2002), and postive overall contributions to performance at the process and firm level (Drnevich and Kriauciunas, 2011). In the context of supply management it is therefore useful to consider how a finely nuanced understanding of core capabilities and routine bundles will contribute to firm performance. This approach will therefore need to investigate the micro foundations of capabilities as, according to Peng et al. (2008), this approach contributes to opening up the black box of the RBV.

Our general approach is supported by Lawson et al. (2009), who argue that while strategic supply management can create alignment with long-term business strategy, it is the regularized deployment of appropriate routines which create the stability to exploit a competitive advantage. Compared with existing theoretical perspectives we disaggregate supply management capabilities into respective routines bundles, broadly similar to the approach used by Peng et al (2008) in their study of innovation and improvement capabilities.

Taking a routines-based approach initially requires making clear the variety of definitions of purchasing capabilities, competences, and practices. Precision about the nature of a capability and routines lays the foundation for a clear-cut differentiation between antecedents to, 
descriptions of behavioural patterns, and strategic outcomes from the deployment of particular patterns of organizational activity.

Capabilities are conceptualised as bundles of interrelated yet distinct routines which evolve over time (Helfat and Peteraf, 2003), and are recurrent processes by which firm resources get utilised to perform a particular activity (Amit and Schoemaker, 1993). An organizational capability therefore is a high-level routine which, together with the implementing inflows, confers upon an organization's management a set of options for producing significant outputs of a particular type (Felin et al, 2012). We define supply management capabilities as bundles of routines comprising ostensive and performative dimensions recurrently utilising resources, with the aim of creating value from supplier interaction. According to Parmigiani and Howard-Grenville (2011) the performative might be thought of as a routine in practice, whilst the ostensive is the routine in principle. Routines are defined by Teece et al. (1997) as the way things are done, or the patterns of activities and when bundled they form capabilities. They are "repetitive, recognizable patterns of interdependent actions, carried out by multiple actors" (Feldman and Pentland, 2003; 95).

Our study is the first to separate out ostensive and performative patterns of routine bundles with supply management capability as a second-order latent construct. This approach is different because of the focus on cross-functional, repetitive routines forming the core of supply management activity, rather than measuring groups of practices which, according to Parmigiani and Howard-Grenville (2014), may be too contextually dependent, idiosyncratic or too narrowly defined around observable practices alone. We seek to examine those routines "stitching together multiple participants and their actions forming patterns repeated across organizations that people can recognize and talk about" (Pentland and Feldman, 2005; 
p. 795). As these capabilities are likely to be path-dependent they justify ongoing managerial attention to avoid firm underperformance (Drnevich and Kriauciunas, 2011).

This paper is organised as follows. In the next section we specify the theoretical nature of a supply management capability enabling us to review and extend theory by specifying a second-order latent variable model and the associated measures. We then review and discuss the results of questionnaire survey research to test the model using structural equation modelling. The paper concludes with theoretical and managerial implications, this study's limitations and future research directions.

\section{Theoretical foundation}

'Routine' and 'capability' get used inter changeably in supply management research to describe various internal practices and patterns of inter-firm interaction, but the field of strategic management is specific in their use to describe different units of analysis for organizational activity. The current lack of precision reflects in the breadth of conceptualisations for supply management capabilities. There is little evidence drawing together a more coherent conceptualisation making it difficult to compare the impact of supply management capabilities on a firm's performance (see Table 1 for a summary of definitions of various constructs). Looking across the various studies two approaches predominate, with each influencing differently the way in which capabilities get measured.

Insert Table 1 Here

\section{Table 1}

A summary of studies using constructs related to supply management capability 
González-Benito's (2007) approach seeks to assess the impact of an outcomes-based competence on performance. This method of studying purchasing strategy conceptualises purchasing capabilities using a modified version of the Vickery (1991) theory of production competence. González-Benito (2007) conceptualises purchasing capabilities in a retrospective, output-based sense using proxies of performance such as quality, cost, flexibility, dependability, and delivery with the firm as the unit of analysis. Krause et al. (2001) advocate a similar approach, using the term "competitive priorities" to assess the key aims of supply management retrospectively. By assessing purchasing decisions through the impact of the level of strategic integration for the function, Carr and Smeltzer (1997) use a related means of evaluating the strategic involvement for purchasing in the firm in alignment with supplier strategies. The principal mechanism uniting these approaches is the measurement of the outcomes from a particular capability which is useful to test retrospectively for fit between the business unit and supply management strategy through measuring the firm's operational performance objectives. Although useful for testing fit, such approaches treat capabilities as "black boxes". Such an approach does not allow for assessing how particular routines form into capabilities, or how routines contribute to organizational goals. A more detailed unit of analysis at the routines-based level is therefore necessary so repeated and reliable patterns of action can be disentangled from those which are ad hoc or cause the firm to alter its resource base.

In contrast, the practice-based approach specifies explicit purchasing practices to establish a purchasing function's task-focused performance. In a sample of manufacturing firms Das and Narasimhan (2000) empirically test 19 purchasing practices which are grouped into what they 
term competences (supply base rationalisation, buyer-supplier relationship development, and supplier evaluation), as measures to assess the impact of particular practices on business performance. Baier et al. (2008) extend this work by testing the interaction effect of strategic orientation on an extended group of purchasing practices. Both studies rely on specifying discrete activities which are implemented by the purchasing function, which is different to assessing generic objectives which result from practices. Although a number of studies (Narasimhan et al., 2001; Ellram et al., 2002; Chen et al., 2004; Das et al., 2006) adopt the practices-based approach, the results of the research are inconclusive.

Reflecting on the mixed results of their study, Ellram et al. (2002) question the specification of practices as a proxy taxonomic classification of supply management activities. They doubt if specifying one comprehensive set of specific practices is able to cover all supply management scenarios from firms across diverse sectors. Also, in order to discern patterns of behavior it will be necessary to separate those supply management routines which are idiosyncratic, or heterogeneous and difficult to imitate, from those which are generic and act as a basic platform for supply management. Furthermore, it remains unclear how the 'collective performance' of a routine fits with measuring performative practices only, as there is an ostensive nature to routines which manifests as abstract patterns that participants use to guide, account for a refer to specific routine performances. By defining supply management capabilities as bundles of routines comprising both ostensive and performative dimensions we open up a new approach for discerning patterns of organizational action. According to Pentland and Feldman (2005) neither the performative or ostensive dimensions can exist without each other as they are mutually constitutive. 
Unlike the production competence and practice-based approaches we use routines as the basis for defining substantial units of activity for a distinct type of recurring supply management resource deployment. Although individual level factors such as personal skill, habits, processbased know how contribute to individual routines, Pentland and Feldman (2005) distinguish organizational routines by their need to involve multiple actors and interdependent actions. According to Pentland and Feldman (2005) the ostensive aspects of a routine may be thought of as a narrative, or script, and they guide, account for, or refer to specific performances of a routine. Artefacts such as rules and written procedures can serve as a proxy for the ostensive aspect of a routine (Pentland and Reuter, 1994). Performative aspects of a routine are commensurate with observable practices and take place against a background of rules, procedures and expectations. This duality also offers a solution to what Cohen $(2007 ; 781)$ terms the "(n)ever changing world" paradox, where routines may be different each time they are observed but retain their characteristic of routineness enabling the identification of more or less the same patterns of action.

Grant (1996) observes that capabilities can be identified and appraised using a standard functional classification of the firm's activities, which get deployed through two categories of routine: “operating" or "search" (Nelson and Winter, 1982; Zott, 2003). An operational capability builds and refines technical fitness, impacting short-term firm performance. Put simply, operational capabilities concern the ability to solve a problem to maintain the status quo (Zahra et al., 2006).

Capabilities persist because of the perceived value achieved from their performance using particular sequences of routines. They are repeated and reliable, and can be improved in performance by trial-and-error learning, repetition, and incremental improvement. Thus, 
Helfat and Winter (2011) summarise the nature of an capability as an enabler for a firm to perform an activity on an ongoing basis using more or less the same techniques, on the same scale, to support existing products or services for the same customer population.

\section{Conceptual framework and hypothesis development}

The routines characterising a supply management capability should encapsulate the diversity of repeated routines involved in day-to-day supplier interaction, both in terms of the observable practices as well as the written rules and scripts for addressing supply management. We draw together studies which have used supply management practices which comprise performative or ostensive characteristics. This synthesis indicates four routines are important for the internal functioning of supply management, albeit the majority are performative in nature (see Table 2).

Insert Table 2 Here

Table 2

A synthesis of routines related to supply management capability

Narasimhan et al. (2001) suggest purchasing competence comprises five routines: (i)

empowerment, (ii) employee competence, (iii) tactical interaction effectiveness, (iv) new product development interaction effectiveness and (v) buyer-supplier relationship management. Two bundles, empowerment and employee competence, characterise functions of job-holder competence that are different units of analysis from routines according to Salvato and Rerup (2011). According to Betsch et al. (2001) they are antecedents to the 
development or operation of a routine so we classify these as different to the unit of analysis for this study. New product development interaction effectiveness is an outcome-based assessment of a dynamic capability which Petersen et al. (2005) argues comprises routines that can act on operational capabilities to change them, and will therefore exhibit features which will be firm and context specific.

In summarising the role of supply management, Chen et al. (2004) highlight three supply management capabilities: (i) fostering close working relationships with a limited number of suppliers, (ii) promoting open communication among supply-chain partners, and (iii) developing long-term strategic orientation to achieve mutual gains. These capabilities match other features empirically investigated by Carr and Smeltzer (2000), who specify those routines key for integrating purchasing within the strategic landscape of the firm. Smeltzer et al. (2003) and Ellram (2006) provide further examples of operational routines, including the use of a sourcing process, and the strategic management of supplier relationships.

Insert Fig. 1 Here

Fig. 1. Second-order factor model for measuring supply management operational capability, four composite routines, and observable activities

We illustrate in Fig. 1 how we conceptualise supply management capability as a second-order latent construct. Reflecting on the outcomes of Table 2 we synthesise four routines central to the internal performance of supply management: the integration of supply management, coordinated sourcing, collaboration management and performance assessment modelled as firstorder latent constructs, reflecting their conceptualisation as routine bundles. Rather than 
practices, routines, and capabilities being interchangeable we separate them out mirroring the approach used by Peng et al. (2008). Thus, we propose the following hypothesis and four sub-hypotheses;

Hypothesis 1. Supply management capability is a second-order latent construct whose subdimensions are supply management integration (H1a), coordinated sourcing (H1b), collaboration management (H1c), and performance assessment (H1d).

\section{Supply management routines}

Supply management integration (SMI) is the alignment and integration of supply management practices across the firm (Narasimhan and Das, 2001), and is a pivotal routine if a firm is to leverage the greatest value from its supply base (Narasimhan and Das, 2001; Chen et al., 2004; Baier et al., 2008). It ensures decisions about supplier management get integrate the requirements of the organisation, and entail extensive engagement with different business functions. According to Carr and Smeltzer (1997) the firm-level performative routine of repeated involvement in top management team meetings is particularly evident of supply management professionals building a degree of influence with other functions within the firm (Ellram et al., 2002). This degree of influence encourages a shared understanding about supply management matters extending across the firm, and results in those with supply management skills being involved in key make or buy decisions. This routine bundle is significant because it demonstrates the cross functional integration of supply management routines into research and development, production and design decisions (Ellram and Carr, 1994; Schiele, 2007). It extends the use of these routines to those responsible for day-to-day supply management, albeit the expertise and design of processes for the management of 
supply relations originates from supply management professionals (Narasimhan et al, 2001; Tracey et al, 2005).

Co-ordinated sourcing $(C S)$ is reflective of the need to formulate sourcing strategies, with evidence showing this group of activities has a direct impact on firm performance (Carr and Smeltzer, 2000; Cousins, 2005). Sourcing involves patterns of resource deployment to plan, implement and control sourcing decisions. Research suggests a broad scope of spend be coordinated using supply management activities to yield the most effective organizational performance, including a clear demarcation of procedures for managing expenditure with suppliers (Baier et al., 2008). These strategic patterns of resource deployment are observable demonstrations that supply management goals will be shared throughout the organisation (Ellram et al., 2002), and permit the ongoing rationalisation of the supply base to permit volume leveraging where appropriate (Narasimhan and Das, 2001).

Collaboration management $(C M)$ requires internal firm actions and decision-making to capture latent value by managing a variety of network interactions which have a direct impact on firm performance (Carr and Pearson, 1999; Wagner and Johnson, 2004). This reflects the recognition that certain relationships will benefit a firm using cooperation rather than competition (Blois, 1972; Aoki, 1988; Dyer, 1997). When relationships are deemed strategic in nature for the buying firm, this decision can trigger more detailed bi-directional information sharing from trust building (Sako, 1992), requiring human and capital investment in the relationship (Esposito and Raffa, 1994; Frohlich and Westbrook, 2001; Lawson et al., 2008). This co-development choice is particularly important given the limited pool of human and capital resources devoted to particular relationships (Asanuma, 1989; Narasimhan et al., 
2001), where reliance is placed on an increasingly smaller, more organized and interconnected pool of suppliers (Colombo and Mariotti, 1998; Chen et al., 2004).

When the firm expects to yield advantages from a supplier relationship they will make longer term investments, even if these results in foregoing some negotiated benefits in the short term (Heide and Miner, 1992). This decision rests on appropriating rents from co-creating value with a partner which exceeds an internal application of resources (Klein et al, 1978). This investment in relationships takes many forms; joint problem solving using mutually acceptable methods of improvement, fostering the relationship to open up developmental opportunities, and ensuring there are avenues to innovate together (Carr and Pearson, 2002). Such opportunities for learning are built on an increasingly co-developed mechanism for exchange where buyers and suppliers share a common language (Nelson and Winter, 1982). We contend, in such circumstances, that opportunities for the routine sharing of innovation will also be shared between close partners.

Performance assessment (PA), according to Paulraj et al. (2006), is a core routine to monitor existing performance, and reflects the necessity of maintaining a system of assessment to avoid supplier opportunism. Such approaches account for the internal and external tracking of performance, which needs a dual internal (self-assessment) and external (supplier) assessment schema. This reflects what Carr and Smeltzer (1997) and Ellram et al. (2002) explain are reporting routines which inform top management about the performance of supply management, and their presence is reflective of good practice. According to Krause et al (1998) the internal control of a supply management capability uses routines assessing both qualitative as well as quantitative measures of performance, whilst the assessment of performance requires clearly defined targets and a processes by which data will be collated 
(Pohl and Förstl, 2011). The assessment process should also track accountability, with Hartmann et al (2012) outlining various stages of evolution to ensure, at the routines level, supply management is kept accountable. This indicates a need for the routine collection of different types of data, with decision-making process about changing the status of relationships relying on codified and repeatedly executed data collecting about performance.

\section{Linking supply management capability with firm performance}

Noordewier et al (1990) state that supply management performance has a legitimate and important impact on firm performance, albeit with the direct nature of practice and performance needing clarity. Carr and Pearson (1999), Carr and Pearson (2002), and Baier, Hartmann and Moser (2008) model a direct relationship between supply management and firm financial performance. Taken as a whole this approach yields mixed results. It therefore seems to be rather optimistic to suggest a direct link between supply management capability and firm financial performance, and suggests there are confounding factors which need to be addressed. We therefore follow a modified version of the approach advocated by Ellram et al (2002) and Singhal and Hendricks (2002), González-Benito (2007) and Chen et al. (2004) demonstrate an indirect effect of supply management capability on company-wide financial performance. We build on these studies using the mediation approach deployed by Hartmann et al (2012), along with tests of the relationship between firm capabilities and company-wide performance (Allred et al., 2011) and how firm-level processes contribute to developing resources that generate economic value (Paulraj, et al, 2006). The current research is concerned with how supply management capability impacts overall operational and financial performance. To ground these results studies within expectations about firm performance from a resource based perspective (e.g., Yeung, 2008) we assert there should be a direct 
relationship between strategic assets and resources tied to a firm and underpinning its overall capabilities (Wernerfelt, 1984). Hence,

Hypothesis 2: Supply management capability does not have a positive impact on firm-level financial performance

Hypothesis 3. Supply management capability has a positive impact on firm-level operational performance

Hypothesis 4. Supply management capability's impact on financial performance is mediated through operational performance, therefore supply management capability does not have a direct impact on firm-level performance.

\section{Research design}

\subsection{Sample frame and data collection procedure}

The population chosen to test the model consists of supply management professionals from a broad range of sectors, who were asked to complete the survey using a firm-level unit of analysis. Most existing research favours the sampling of manufacturing-based firms (Narasimhan and Das, 2001; Chen et al., 2004). However, we chose to widen the sample frame to include a variety of industries. We did this to take into account supply management routines across firms where purchasing covers physical items as well as the procurement of intangibles such as business services, advertising, or facilities management. Supply managers were chosen as target respondents as they are most closely involved in the day-to-day operation of the routine bundles in question. To capture the key constructs, supply 
management capability and performance, our survey instrument contained five point Likert type scales (see Appendix 1).

We collected the data using a survey instrument circulated by mail in 2009 to 4,000 individuals based in the United Kingdom, drawing the sample of middle and senior managers from the membership list of the Chartered Institute of Purchasing and Supply. We chose to target middle and senior managers as we expect this grouping to have an overview of routines both within and outwith functional boundaries. A total of 601 surveys were returned. The survey responses were subject to a number of standard procedures (e.g., box plots, Mahalanobis distance) to check for outliers (Hair et al., 2010). This process resulted in the elimination of a small number of outlying observations. After eliminating outliers and surveys with excessive missing values (Olinsky et al., 2003), a sample of 510 usable responses (response rate of 13\%) remained for use in subsequent analysis. The response rate compares favourably with other research of a similar nature (e.g., Narasimhan et al., 2001; Baier et al., 2008).

Consistent with Dillman's tailored design method (Dillman, 2007), a personalised letter accompanied the paper survey, followed by two further mail-outs sent to those who had not returned the initial questionnaire three and six weeks after the first questionnaire was sent. In an effort to increase the response rate we offered the opportunity to provide respondents a complimentary copy of the results.

To evaluate non-response bias as well as to rule out systematic differences between responses received at various stages of the data-collection process, we use analysis of variance to compare sets of responses, including early vs. late responses (Armstrong and Overton, 1977). 


\subsection{Measurement development}

As discussed in section 3 supply management capability (SMC) is a second-order factor and we measure this through four distinct routine bundles supply management integration (SMI), coordinated sourcing (CS), collaboration management (CM) and performance assessment (PA) (see Appendix 1).

We use a multi-item scale to measure each routine, and as there is no extant scale for each routine bundle we have followed a rigorous four-stage item purification process guided by Churchill's (1979) process of construct development. First, we reviewed the relevant literature pertaining to supply management capabilities and other related constructs. To establish the content validity of the measures, we included items from previous studies when they reflected the routine's definition. Second, we further improved the content validity of the items by conducting a one-day workshop where a group of ten senior practitioners assessed the capability scale in two steps; they examined its completeness in terms of routines, and then each of the routines for their theoretical composition reflecting the need to establish ostensive and performative measures. We videoed the workshop, which allowed the research team to re-assess the discussions and draw out the implications for each routine. Third, we distributed the scale to a separate group of nine practitioners, then to nine academics for review. Stages two and three in particular helped reduce common method variance and potential common method bias, and will have contributed to responses of superior quality (Venkatraman and Grant, 1986). The fourth stage involved a pilot study of the survey instrument. We asked 1,000 randomly selected members of a target group closely matching but different from the main study population to complete the survey following the 
same instrument distribution method as the final survey. At each stage, if the research team considered alterations necessary, they offered suggestions and made changes. Appendix 1 details the measurement items for the four routines and firm performance.

As in previous research into the relationship between capabilities and performance (e.g., Peng et al., 2008), we favour self-reported performance over objective measures of performance, owing to the difficulties associated with comparable measures of performance for large samples (Youndt et al., 1996; Klassen and Whybark, 1999; Narasimham and Das, 2001) and because previous research has shown a high degree of correspondence between self-reported subjective performance estimations and objective data. This gives strong support for the validity and reliability of the subjective measurement technique (Dess and Robinson 1984; Hart and Banbury, 1994; Pearce et al., 1987; Venkatraman and Ramanujam, 1986).

Dess and Robinson's (1984) three-item scale, refined by Pearce et al. (1987), is used to measure financial performance (FIN_PERF) and assesses overall financial performance, return on investment and growth in the volume of sales. We measure company-wide operational performance (OPS_PERF) by adopting Thomas and Ramaswamy’s (1996) operational measures of research and development, ratio of research and development to total sales, cost reduction, ratio of costs of goods sold to total sales and converted into perceptual scales. Broadly similar scales for firm performance are used by Kannan and Tan (2006) and Carr and Pearson (1999), which according to Tan et al (1998) have been commonly used in a number of supply management studies. Each of these items is measured over the last three years in relation to the performance of competitors on a 5-point Likert scale from "much worse" to "much better". A 1-item purchasing performance measure, number of joint company/supplier innovations implemented, by Ellram and Liu (2002), replaced Asset 
intensity, total assets per employee (one of the measures used in Thomas and Ramaswamy's (1996) original scale), because the pilot study revealed that respondents could not answer the question reliably. The Thomas and Ramaswamy (1996) operational measure of Market focus, ratio of marketing expenditure to total sales was also included.

The univariate distributional properties of the data were examined with all items substantially conform to normality. Furthermore, we investigated significant deviation from the neutral response for all items. All were significantly different from three for both supply management capability and performance. Since one respondent at each firm provided the data for our study, we tested for the effects of common method variance by conducting Harman's single-factor test (Podsakoff and Organ, 1986), the most widely used method to evaluate the possibility of common method variance (Podsakoff et al., 2003). We did not find any general factor which accounted for most of the variance in these variables, so we conclude that common method variance is not a problem in our study (Podsakoff and Organ, 1986).

\section{Results}

The covariance based structural equation modelling (C-B SEM) approach is used to simultaneously examine both the measurement and structural models (Hair et al, 2010; Byrne, 2001; Hoyle, 1995). C-B SEM is appropriate for this study whose focus is both on theory confirmation and theory development. The empirical assessment follows the "two-step approach" recommended by Anderson and Gerbing (1988). First, the measurement model reliability and validity are considered, followed an evaluation of the path coefficients within the structural model. 
The AMOS 22 software is used and although the data do not confirm to multivariate normality, maximum likelihood procedure (ML) is used (multivariate Kurtosis $=93.247$; critical ratio $=33.877)$. Chou and Bentler $(1995$ p.38) observe that "ML estimates have been found to be quite robust to violation of normality" and will produce "good estimates" in terms of their biasness and consistency. Several studies (Hu et al, 1992; Olsson et al, 2000), demonstrate that ML “outperform" alternative estimation procedures like generalized least squares (GLS) (Schermelleh-Engel et al, 2003)

Confirmatory factor analysis (CFA) is used to assess two measurement models. Model 1 includes all the latent constructs in a first order structure. Model 2 considered SMC as a second order construct.

\subsection{Measurement model 1: All first order constructs}

The measurement model is tested using (CFA) (Hair et al, 2010; Bryne, 2001).

Conventionally, $\chi^{2}$ measures overall goodness of fit for the hypothesised model to reproduce the sample data $\left(\chi^{2}=321.218, d f=171, \mathrm{p}=0.000\right)$. However, "given the known sensitivity of this statistic $\left(\chi^{2}\right)$ " (Byrne, 2001 p.152-3), particularly to sample size, a number of heuristic indices facilitate a statistical judgement on the goodness of fit. Those reported here, together with accepted relative benchmarks, are recommended by Hair et al, 2010; Schermelleh-Engel et al, 2003; Bryne, 2001; Archbuckle and Wothke, 1999 and Hoyle et al, 1995) (see Table 3).

Insert Table 3 Here

Table 3. Goodness of fit indices for the first order measurement model 
All goodness of fit indices surpass the required values indicating that the hypothesised covariance relationship between reflective latent constructs and their items is statistically plausible.

The issues of reliability and validity of measurement model are next considered. The internal consistency index for each construct exceed 0.7 except for one $\left(\mathrm{OPS} \_\right.$PERF $\left.=0.671\right)$, indicating an acceptable degree of reliability.

Two aspects of validity: convergent validity and discriminant validity are examined. For all constructs convergent validity, assessed by the average variance extracted (AVE), meets the criterion of 0.5 set by Fornell and Larcker (1981). Thus each latent variable explains on average more than $50 \%$ of the variance of its indicators (Götz et al, 2009).

Insert Table 4 Here

Table 4: First order measurement model - standardized loadings

Insert Table 5 Here

Table 5: Discriminant validity of first-order constructs

Since the square root of each construct's AVE is greater than the bivariate correlation with the other constructs in the model discriminant validity is confirmed (Chin, 1998) (see Table $5)$. 
The conceptual rationale for SMC as a second order construct with four first order dimensions is given in section 3 and presented in Figure 1. Although $\chi^{2}$ is significant $\left(\chi^{2}=\right.$ 205.477, $d f=97, \mathrm{p}=0.000)$, all conventional goodness of fit diagnostics meet the acceptable benchmarks (Table 6). Furthermore, (i) the four regression weights of SMC on its dimensions SMI, CS, CM and PA are significant at $\mathrm{p}<0.001$ and (ii) the sixteen loadings of the four dimensions on their items are significant at $\mathrm{p}<0.001$ (see Table 7).

Insert Table 6 Here

Table 6: Goodness of fit indices for the second order measurement model for SMC

To statistically validate the existence of higher order structure the target-coefficient $(\mathrm{T})$ (Marsh and Hocevar, 1985) was calculated. T is a ratio of the chi-square given the first order measurement model for SMI, CS, CM and PA to the chi-square given second order measurement model for SMC $-\mathrm{T}=\left[\chi^{2} 1^{\text {st }}\right.$ Order $] / \chi^{2} 2^{\text {st }}$ Order $]=201.409 / 205.477=0.980$. This exceeds 0.7 indicating that the major variance among SMI, CS, CM and PA is captured by the higher order construct SMC (Segars and Grover, 1998). In addition, the second order structure is more parsimonious (Rindskopf and Rose, 1988) thus providing further justification for it use.

Insert Table 7 Here

Table 7: Second order measurement model SMC - standardized weights and loadings 


\subsection{Structural model evaluation}

Our research model embeds SMC in a causal mediating network with OPS_PERF and FIN_PERF. The overall goodness of fit of the hypothesized relationships is examined using the same criteria as those for CFA (see Table 8). Although the $\chi^{2}$ is significant $\left(\chi^{2}=335.394\right.$, $d f=179, \mathrm{p}=0.000)$ all the heuristic indices surpassed the accepted benchmarks.

-Insert Table 8 Here

Table 8: Goodness of fit indices for the structural model

Thus, we proceed to the regression weights between the exogenous variable (SMC), intervening endogenous variable (PERF_OPS) and the determined endogenous variable (PERF_FIN) to validate $\mathrm{H}_{2} ; \mathrm{H}_{3}$ and $\mathrm{H}_{4}$ (see Figure 2).

-Insert Table 9 Here

Table 9: Structural mediating model via OPS_PERF - regression weights

-Insert Fig 2 Here

Fig. 2: Structural mediation model 
The direct effect $\mathrm{SMC} \rightarrow$ FIN_PERF (-0.034) is low, negative and insignificant; whereas, the individual components of the indirect effect SMC $\rightarrow$ OPS_PERF $(0.334 ; \mathrm{p}<0.001)$ and OPS_ $\rightarrow$ FIN_PERF $(0.876 ; \mathrm{p}<0.001)$ are highly significant thus lending support to $\mathrm{H}_{2}$ and $\mathrm{H}_{3}$ respectively. The indirect effect is obtain by the product $(\mathrm{SMC} \rightarrow$ OPS_PERF)*(OPS $\rightarrow$ FIN_PERF) $=0.293$ (Baron and Kenny, 1986). Using the Sobel test the indirect effect is also significant at the 0.01 level $(z$-statistic $=4.435)($ Sobel, 1982). Since the direct effect is insignificant and the indirect effect is significant this confirms support to $\mathrm{H}_{4}$, the positive effect of SMC on FIN_PERF is fully mediated by OPS_PERF ( Liao and Kuo, 2014; Holmbeck, 1997; Baron and Kenny, 1986). Overall, the proposed research model with its higher order latent structure performs well and provides supporting evidence for our hypothesised relationships.

\section{Discussion and conclusions}

The primary contribution of this research is to separate out the contribution of supply management capability comprising four routine bundles and test its impact on firm financial and operational performance. Our approach therefore clarifies the ambiguity in defining and conceptualizing supply management routines and capabilities using both ostensive and performative routines. In doing so we provide evidence that day-to-day routines associated with supply management capability impact firm performance. Second, our results demonstrate a strong, mediated effect on financial performance for supply management capability, and complement the study of dynamic capabilities by Allred et al. (2011), who find a similar indirect impact. However, when the relationship between supply management capability and financial performance is mediated there is an insignificant but negative correlation with financial performance. This needs to be considered in respect of similar 
results identified by Baier, Hartmann and Moser (2008) where, when firms follow a differentiation strategy results in a direct negative financial performance. Our findings therefore share similarities with those of Hartmann et al (2012) and Ellram et al (2002) who find there is no direct relationship between purchasing maturity and financial performance. Our model suggests that supply management capability primarily improves the operational performance of the business, which subsequently gets translated into improved financial performance. This provides further evidence, following the same line of argument of Ellram et al (2002), to suggest that supply management acts primarily in a support role, using capabilities such as reaching out to suppliers for innovation and reducing waste which reflect in more effective business strategy, better products or services, and more effective business processes.

Third, a routines-based approach has allowed us to demonstrate a different, more fine-grained approach for assessing consistent bundles of homogeneous patterns of activity across firms. Our findings therefore provide a new perspective on the scope of the term "best practice", which we consider having a limited but important use in describing supply management capabilities. Our research responds to Ellram et al (2002) who call for further insights into this 'best practices' debate, with our approach contributing to a more comprehensive method for assessing supply management maturity, as existing approaches fall back on describing practices alone without the associated ostensive aspects of routines (c.f. Ellram et al, 2002, Schiele, 2007). The results suggest there is a considerable performance impact from what are described as "tactical" activity patterns on operational performance, comprising day-to-day routines nested within an overall supply management capability. Rather than assuming that operational capabilities connote practices which are strategically unimportant, our results indicate a need to pay attention to the development of these types of routine bundle both in 
terms of their tacit (ostensive) and explicit (performative) features. They should therefore be re-framed as valuable contributors to short-term firm performance, as we demonstrate the 'executional premium' in performance to be gained for firms when seeking to improve their operational capabilities.

Finally, the initial complexity addressed by this research is to resolve the historical ambiguity in the specific nature of a supply management capability, and how to conceptualise routine bundles. We clarify a path through this, choosing to rebalance the application of RBV in the supply management context by considering both ostensive and performative measures. There is a need for research to assess routines which build value for the "here and now" being equally important to consider as those which reconfigure, renew, and search for new capabilities. Our evidence, in summary, suggests a pattern of routines which appear to be the constituents of a core architecture for supply management capability.

\subsection{Managerial implications}

Practitioners benefit from a series of important outcomes from this research. The key finding is a process-embedded insight from supply management professionals: specific 'core' routines have a differential effect on performance. This research indicates it is useful to learn and perfect particular patterns of day-to-day activity such as the co-ordination of purchases across the organization, enabling methods to assess the firm's total expenditure with suppliers, and business process which control the cost of inputs from suppliers.

Furthermore, it is striking that such routines, and those involving collaboration management, might not simply be within the control and remit of supply management personnel. It will be 
instructive for practitioners therefore to consider how the development, control and accountability for repeated and reliable routines inter-play with how supply management capability is executed. In essence, it seems that a routine-based perspective of supply management may enable a more cross-functional way of 'seeing' how supply management occurs within and between organizations.

Our results also demonstrate an indirect effect on performance for supply management capability. Although there is a clear, face-valid rationale for the primary role of supply management to be a controller of costs (c.f. Nollet et al 2008), our results confirm this activity impacts the financial performance of the organisation indirectly. This may be at odds with practices which place too much importance on directly measuring supply management capability predominantly using the financial performance of the business. This important finding supports the assertion from Narasimhan and Das (2001) and Reuter et al (2010) to suggest that supply management professionals should seek to justify their contribution to the firm on a wider basis than placing emphasis on financial metrics. Operational performance is an important mediating step, and therefore its measurement should be given greater consideration. Finally, considering this mediating effect it could be speculated that a 'lag' effect occurs from the realization of successful operational execution, which is revealed in later time periods of financial performance reporting.

\subsection{Limitations and further research}

This research is subject to a series of limitations, which provide the start points for future avenues of enquiry. Our model is the first of its kind to consider the role of ostensive and performative features of supply management routines. Our scale is therefore embryonic and 
will benefit from development as more capabilities and routines are identified so it can grow into a fully comprehensive measurement instrument. Future research should assess the breadth of measures so they capture the full extent of the underlying first-order constructs. Our model is therefore deliberately conservative, and will need to be augmented with other items or routines. For instance, in their purchasing practices model Ellram et al. (2002) include market monitoring for technology, pricing, and product/service availability as features of the supply management task. We have traded off the integration of detailed elements to test the overall rationale of routine bundles as features of capabilities. We have therefore concentrated on a higher level of abstraction for the sourcing process as a direction-setting task. Future research could therefore fruitfully develop more detailed and fine-grained measures for each routine, and where necessary add new routines to increase the explanatory power of constructs.

With the further development of measures for capabilities it may be possible to compare exploitation and exploitation: operational and dynamic, as they contribute differently to firm performance. The general idea behind the dynamic capabilities perspective is firms "combining" and "recombining" capabilities to form newer ones that suit their environment and are able to do so better than the competition. In the light of this view, future research may wish to consider research directions which address the issues in this paper in the context of environments with different levels of munificence.

Although we demonstrate through our findings that routines have a net contributory effect on firm performance, it could reasonably be assumed that certain operational capabilities have variable impacts on performance. It would be useful, therefore, to assess whether particular routines have an initially negative effect if pursued in a particularly poor manner, or when 
embryonic in their adoption. This augments the approach advocated by Rozemeijer (2008) who suggests a more simplistic, uniform evolution of supply management capability. This suggestion introduces the possibility of several confounding effects on performance; improving particular routines to deal with poor execution, the need to "fit" a routine with the strategic focus of the firm, or the differential path dependencies in terms of learning for particular routines.

One further avenue following from the path dependency of routines is the deeper and more finely nuanced nature of the interplay between routines and capabilities over time. This will require the use of simulations or more longitudinal methods to investigate how operational routines become learned, whether there are particular operational routines which are truly idiosyncratic in nature, and the speed of development for operational capability.

It is interesting to note that many papers measure routines use Likert-type scales as an ordinal, not a cardinal value. Future papers should justify why it is possible to use ordinal scales as cardinal scales. Future research may wish to transform the ordinal scale into a fuzzy number, use fuzzy operators and fuzzy relations, de-fuzzify the result and then use a statistical approach (if needed).

Finally, the sample we draw from is limited to UK managers who hold membership of the Chartered Institute of Purchasing and Supply. Although the sample group (middle and senior managers across multiple sectors) are expected to have a depth of knowledge about routines related to supply management it may be useful to compare samples from other countries, similar to the approach used by Peng et al (2008). 
Table 1: A summary of studies using constructs related to supply management capability

\begin{tabular}{|c|c|c|c|c|c|}
\hline Construct & Study & Definition & $\begin{array}{l}\text { Dimensions and } \\
\text { Operationalisation }\end{array}$ & $\begin{array}{l}\text { Study Sample } \\
\text { Characteristics }\end{array}$ & $\begin{array}{l}\text { Dependent } \\
\text { Variables }\end{array}$ \\
\hline \multirow[t]{2}{*}{$\begin{array}{l}\text { Purchasing } \\
\text { competence }\end{array}$} & $\begin{array}{l}\text { (Das and } \\
\text { Narasimhan, } \\
2000)\end{array}$ & $\begin{array}{l}\text { The capability to structure, develop and manage } \\
\text { the supply base in alignment with the } \\
\text { manufacturing and business priorities of the } \\
\text { firm. }\end{array}$ & $\begin{array}{l}\text { Performative practices related to } \\
\text { the latent constructs of buyer- } \\
\text { supplier relationship development, } \\
\text { parts bundling, supplier capability } \\
\text { auditing and purchasing integration }\end{array}$ & $\begin{array}{l}322 \text { responses from } \\
\text { five manufacturing } \\
\text { sectors }\end{array}$ & $\begin{array}{l}\text { New product development time performance; manufacturing } \\
\text { cost performance; quality performance; delivery } \\
\text { performance; customisation responsiveness performance }\end{array}$ \\
\hline & $\begin{array}{l}\text { (González- } \\
\text { Benito, 2007) }\end{array}$ & $\begin{array}{l}\text { Two components: the fit between purchasing } \\
\text { strategic objectives and purchasing capabilities, } \\
\text { and the fit between the business strategy of the } \\
\text { firm and purchasing strategic objectives. }\end{array}$ & $\begin{array}{l}\text { The strategic relevance and } \\
\text { achieved performance of generic } \\
\text { purchasing objectives (cost; quality; } \\
\text { flexibility; delivery; dependability) }\end{array}$ & $\begin{array}{l}141 \text { responses from } \\
\text { three Spanish } \\
\text { manufacturing sectors }\end{array}$ & $\begin{array}{l}\text { Sales growth; reputation and image; customer satisfaction; } \\
\text { market share (of the main product); success of new product } \\
\text { launches; profits as \% of sales; labor productivity }\end{array}$ \\
\hline \multirow[t]{2}{*}{$\begin{array}{l}\text { Strategic } \\
\text { purchasing }\end{array}$} & $\begin{array}{l}\text { (Paulraj et al., } \\
\text { 2006). }\end{array}$ & $\begin{array}{l}\text { The efforts taken by the purchasing function that } \\
\text { may include a variety of roles ranging from } \\
\text { supportive to strategic in nature. }\end{array}$ & $\begin{array}{l}\text { Strategic focus; strategic } \\
\text { involvement; visibility/status }\end{array}$ & $\begin{array}{l}232 \text { responses from six } \\
\text { manufacturing sectors }\end{array}$ & $\begin{array}{l}\text { Supplier (procurement) performance; buyer performance; } \\
\text { financial performance }\end{array}$ \\
\hline & $\begin{array}{l}\text { (Carr and } \\
\text { Pearson, } \\
\text { 1999). }\end{array}$ & $\begin{array}{l}\text { The process of planning, evaluating, } \\
\text { implementing, and controlling strategic and } \\
\text { operating purchasing decisions. }\end{array}$ & $\begin{array}{l}\text { Strategic planning; buyer-supplier } \\
\text { relationships; supplier evaluation } \\
\text { systems }\end{array}$ & $\begin{array}{l}163 \text { responses from } \\
\text { manufacturing and } \\
\text { non-manufacturing } \\
\text { firms }\end{array}$ & $\begin{array}{l}\text { Financial performance (return on investment, profits as \% of } \\
\text { sales, net income before taxes, present value of the firm) }\end{array}$ \\
\hline $\begin{array}{l}\text { Supply } \\
\text { management } \\
\text { capabilities }\end{array}$ & $\begin{array}{l}\text { (Chen et al., } \\
\text { 2004). }\end{array}$ & $\begin{array}{l}\text { The effective management of supply-chain } \\
\text { partnerships using close relationships with a } \\
\text { limited number of suppliers, a long-term } \\
\text { orientation and communication. }\end{array}$ & $\begin{array}{l}\text { Mix of outcomes (Limited number } \\
\text { of suppliers) and practices (strategic } \\
\text { purchasing; long-term orientation; } \\
\text { communication) }\end{array}$ & $\begin{array}{l}232 \text { responses from six } \\
\text { manufacturing sectors }\end{array}$ & Customer responsiveness; financial performance \\
\hline $\begin{array}{l}\text { Purchasing } \\
\text { practices }\end{array}$ & $\begin{array}{l}\text { (Baier et al., } \\
\text { 2008) }\end{array}$ & $\begin{array}{l}\text { Purchasing practices are closely related to day- } \\
\text { to-day activities, and are internal to the } \\
\text { purchasing function. }\end{array}$ & $\begin{array}{l}\text { Individual mind-sets and } \\
\text { aspirations; Practices (talent } \\
\text { management; purchasing } \\
\text { integration; organisation structure; } \\
\text { cross-functional collaboration; } \\
\text { performance management; } \\
\text { knowledge and information; supply } \\
\text { strategy; core purchasing processes; } \\
\text { supplier management) }\end{array}$ & $\begin{array}{l}161 \text { responses from } \\
\text { eight sectors }\end{array}$ & $\begin{array}{l}\text { Financial performance: annual reduction of cost of goods } \\
\text { sold, annual sales growth, return on assets, EBITDA margin }\end{array}$ \\
\hline $\begin{array}{l}\text { Purchasing } \\
\text { skills }\end{array}$ & $\begin{array}{l}\text { (Carr and } \\
\text { Smeltzer, } \\
\text { 2000). }\end{array}$ & $\begin{array}{l}\text { Purchasing skills are required before tasks } \\
\text { associated with planning, implementing, } \\
\text { controlling, and evaluating strategic and } \\
\text { operational purchasing decisions. }\end{array}$ & $\begin{array}{l}\text { Evidence of individual skills \& their } \\
\text { spread (skills techniques; } \\
\text { behavioural skills; technical skills) }\end{array}$ & $\begin{array}{l}163 \text { responses from } \\
\text { manufacturing and } \\
\text { non-manufacturing } \\
\text { sectors }\end{array}$ & $\begin{array}{l}\text { Firm performance (return on investment, profit as } \% \text { of } \\
\text { sales, sales growth, market share, net income before taxes); } \\
\text { supplier responsiveness (material quality, materials delivery } \\
\text { material price, flexibility) }\end{array}$ \\
\hline $\begin{array}{l}\text { Purchasing } \\
\text { competitive } \\
\text { priorities }\end{array}$ & $\begin{array}{l}\text { (Krause et al., } \\
2001)\end{array}$ & $\begin{array}{l}\text { The stream of decisions made by purchasing } \\
\text { personnel in areas that are critical for } \\
\text { purchasing. }\end{array}$ & $\begin{array}{l}\text { Mix of outcome-based purchasing } \\
\text { objectives (quality, delivery, cost, } \\
\text { flexibility, and innovation) }\end{array}$ & $\begin{array}{l}252 \text { responses from } \\
\text { manufacturing-based } \\
\text { industries }\end{array}$ & $\begin{array}{l}\text { Not relevant to the study as the focus was to scale build } \\
\text { using CFA rather than assess the impact of purchasing } \\
\text { priorities on a dependent variable. }\end{array}$ \\
\hline
\end{tabular}


Table 2: A synthesis of routines related to supply management capability

\begin{tabular}{|c|c|c|}
\hline Nature of Routine & Summarised Patterns of Resource Deployment & Relevant Empirical Studies \\
\hline Coordinated sourcing & $\begin{array}{l}\text { - A supply management strategy is developed and clearly articulated, covering the whole } \\
\text { supply base. } \\
\text { - There are strategic plans which considerably impact the nature of the firm's expenditure } \\
\text { with and relationship to suppliers. } \\
\text { - Strategic direction setting benefits from a full oversight of the organisation's contractual } \\
\text { commitment to suppliers and level of expenditure with suppliers. } \\
\text { - Authorisations for expenditure with suppliers will be internally controlled, reflecting } \\
\text { principles of supply base rationalisation and clear accountabilities for spend. }\end{array}$ & $\begin{array}{l}\text { (Narasimhan and Das, 2001), } \\
\text { (Humphreys et al., 2008), (González- } \\
\text { Benito, 2007), (Baier et al., 2008), (Carr } \\
\text { and Smeltzer, 1997) }\end{array}$ \\
\hline Collaboration management & $\begin{array}{l}\text { - Relationships are developed with certain suppliers on a long-term basis by regularly } \\
\text { seeking to build collaboration and involvement from suppliers, involving face-to-face } \\
\text { contact. } \\
\text { - Structured joint problem-solving processes are used to deal with supply management } \\
\text { issues. } \\
\text { - Information sharing takes place with certain suppliers. } \\
\text { - The size of the supply base is monitored regularly to ensure it meets the needs of the } \\
\text { firm. } \\
\text { - Continuous improvement processes are used to incrementally remove waste from supply } \\
\text { chain processes. }\end{array}$ & $\begin{array}{l}\text { (Chen et al., 2004), (Ellram et al., 2002), } \\
\text { (Narasimhan et al., 2001), (Carr and } \\
\text { Smeltzer, 1997), (Krause et al., 1998), } \\
\text { (Lawson et al., 2009), (Krause et al., } \\
\text { 2007), (Choi and Hartley, 1996), } \\
\text { (Mahapatra et al., 2010), (Paulraj et al., } \\
\text { 2008) }\end{array}$ \\
\hline Performance assessment & $\begin{array}{l}\text { - Objective financial and non-financial goals for supply management are shared } \\
\text { throughout the organisation, including with senior managers. } \\
\text { - Formal assessment processes operate to monitor the performance of supply management } \\
\text { activities. } \\
\text { - Suppliers' capabilities are performance assessed, according to current organisational } \\
\text { needs. }\end{array}$ & $\begin{array}{l}\text { (Krause et al., 1998), (Zsidisin and } \\
\text { Ellram, 2001), (Pohl and Förstl, 2011), } \\
\text { (Spekman et al., 1999), (Smeltzer et al., } \\
\text { 2003), (Takeishi, 2001), }\end{array}$ \\
\hline
\end{tabular}


Table 3: Goodness of fit indices for the first order measurement model

\begin{tabular}{|l|c|c|}
\hline \multicolumn{1}{|c|}{$\begin{array}{c}\text { Goodness of fit } \\
\text { measures }\end{array}$} & $\begin{array}{c}\text { Recommended } \\
\text { Values }\end{array}$ & Results \\
\hline$\chi^{2} / \mathrm{df}$ & $\leq 3.00$ & 1.878 \\
\hline GFI & $\geq 0.90$ & 0.943 \\
\hline AGFI & $\geq 0.85$ & 0.923 \\
\hline CFI & $\geq 0.95$ & 0.966 \\
\hline NFI & $\geq 0.90$ & 0.930 \\
\hline SRMR & $\leq 0.10$ & 0.043 \\
\hline RMSEA & $\leq 0.08$ & 0.042 \\
\hline
\end{tabular}


Table 4: First order measurement model - standardized loadings

\begin{tabular}{|c|c|c|c|c|c|c|}
\hline $\begin{array}{l}\text { Observable } \\
\text { Item Code }\end{array}$ & $\begin{array}{l}\text { Observable } \\
\text { Item Name }\end{array}$ & & $\begin{array}{c}\text { First Order } \\
\text { Construct }\end{array}$ & $\lambda$ & $\rho_{c}$ & AVE \\
\hline $\mathrm{X} 11$ & SMI_attend & $\leftarrow$ & SMI & $0.602 *$ & 0.755 & 0.507 \\
\hline $\mathrm{X} 12$ & SMI_influence & $\leftarrow$ & SMI & $0.629 *$ & & \\
\hline $\mathrm{X} 13$ & SMI_makebuy & $\leftarrow$ & SMI & $0.637 *$ & & \\
\hline $\mathrm{X} 21$ & CS_comm & $\leftarrow$ & $\mathrm{CS}$ & $0.804 *$ & 0.872 & 0.697 \\
\hline $\mathrm{X} 22$ & CS_total & $\leftarrow$ & $\mathrm{CS}$ & $0.785^{*}$ & & \\
\hline $\mathrm{X} 23$ & CS_effect & $\leftarrow$ & $\mathrm{CS}$ & $0.667 *$ & & \\
\hline X31 & CM_joint & $\leftarrow$ & $\mathrm{CM}$ & $0.688^{*}$ & 0.898 & 0.595 \\
\hline X32 & CM_long & $\leftarrow$ & $\mathrm{CM}$ & $0.650 *$ & & \\
\hline X33 & CM_strat & $\leftarrow$ & $\mathrm{CM}$ & $0.688 *$ & & \\
\hline X34 & CM_waste & $\leftarrow$ & $\mathrm{CM}$ & $0.730^{*}$ & & \\
\hline $\mathrm{X} 35$ & CM_new & $\leftarrow$ & $\mathrm{CM}$ & $0.723 *$ & & \\
\hline X36 & CM_first & $\leftarrow$ & $\mathrm{CM}$ & $0.616^{*}$ & & \\
\hline $\mathrm{X} 41$ & PA_quant & $\leftarrow$ & $\mathrm{PA}$ & $0.918^{*}$ & 0.911 & 0.724 \\
\hline $\mathrm{X} 42$ & PA_qual & $\leftarrow$ & $\mathrm{PA}$ & $0.852 *$ & & \\
\hline $\mathrm{X} 43$ & PA_smat & $\leftarrow$ & $\mathrm{PA}$ & $0.668 *$ & & \\
\hline \multirow[t]{7}{*}{$\mathrm{X} 44$} & PA_targets & $\leftarrow$ & $\mathrm{PA}$ & $0.638 *$ & & \\
\hline & FIN_overall & $\leftarrow$ & FIN_PERF & $0.839 *$ & 0.899 & 0.748 \\
\hline & FIN_roi & $\leftarrow$ & FIN_PERF & $0.777 *$ & & \\
\hline & FIN_vol & $\leftarrow$ & FIN_PERF & $0.752 *$ & & \\
\hline & OPS_RD & $\leftarrow$ & OPS_PERF & $0.571^{*}$ & 0.671 & 0.506 \\
\hline & OPS_mkt & $\leftarrow$ & OPS_PERF & $0.671^{*}$ & & \\
\hline & $\begin{array}{l}{ }^{*} p<0.001 \\
t \text {-values } 8.70\end{array}$ & to & 4.172 & & & \\
\hline
\end{tabular}


Table 5: Discriminant validity for first order constructs

\begin{tabular}{|l|r|r|r|r|r|l|}
\hline & \multicolumn{1}{|l|}{ SMI } & \multicolumn{1}{l|}{ CS } & \multicolumn{1}{l|}{ CM } & PA & FIN & OPS \\
\hline SMI & $\mathbf{0 . 7 1 2}$ & & & & & \\
\hline CS & 0.531 & $\mathbf{0 . 8 3 5}$ & & & & \\
\hline CM & 0.620 & 0.715 & $\mathbf{0 . 7 7 9}$ & & & \\
\hline PA & 0.384 & 0.542 & 0.650 & $\mathbf{0 . 8 5 1}$ & & \\
\hline FIN & 0.164 & 0.140 & 0.272 & 0.129 & $\mathbf{0 . 8 6 5}$ & \\
\hline OPS & 0.292 & 0.204 & 0.408 & 0.299 & 0.706 & $\mathbf{0 . 7 1 1}$ \\
\hline
\end{tabular}

Off diagonals are bivariate correlations, bold main diagonals are square root of corresponding AVE

Table 6: Goodness of fit indices for the second order measurement model for SMC

\begin{tabular}{|l|c|c|}
\hline Goodness of fit measures & Recommended Values & Results \\
\hline$\chi^{2} / \mathrm{df}$ & $\leq 3.00$ & 2.118 \\
\hline GFI & $\geq 0.90$ & 0.950 \\
\hline AGFI & $\geq 0.85$ & 0.930 \\
\hline CFI & $\geq 0.95$ & 0.969 \\
\hline NFI & $\geq 0.90$ & 0.943 \\
\hline SRMR & $\leq 0.10$ & 0.044 \\
\hline RMSEA & $\leq 0.08$ & 0.047 \\
\hline
\end{tabular}


Table 7: Second order measurement model SMC - standardized weights and loadings

\begin{tabular}{|c|c|c|c|c|c|}
\hline $\begin{array}{c}\text { Observable } \\
\text { Item Code }\end{array}$ & & & & $\begin{array}{c}\text { Weights } \\
\gamma\end{array}$ & $\begin{array}{c}\text { Loadings } \\
\lambda\end{array}$ \\
\hline & SMI & $\leftarrow$ & SMC & $0.649 *$ & \\
\hline & CS & $\leftarrow$ & SMC & $0.772 *$ & \\
\hline & $\mathrm{CM}$ & $\leftarrow$ & SMC & $0.942 *$ & \\
\hline & $\mathrm{PA}$ & $\leftarrow$ & SMC & $0.685^{*}$ & \\
\hline $\mathrm{X} 11$ & SMI_attend & $\leftarrow$ & SMI & & $0.604^{*}$ \\
\hline $\mathrm{X} 12$ & SMI_influence & $\leftarrow$ & SMI & & $0.620^{*}$ \\
\hline $\mathrm{X} 13$ & SMI_makebuy & $\leftarrow$ & SMI & & $0.645^{*}$ \\
\hline $\mathrm{X} 21$ & CS_comm & $\leftarrow$ & $\mathrm{CS}$ & & $0.784^{*}$ \\
\hline $\mathrm{X} 22$ & CS_total & $\leftarrow$ & CS & & $0.666^{*}$ \\
\hline $\mathrm{X} 23$ & CS_effect & $\leftarrow$ & $\mathrm{CS}$ & & $0.804 *$ \\
\hline X31 & $\mathrm{CM}_{\text {_joint }}$ & $\leftarrow$ & $\mathrm{CM}$ & & $0.692^{*}$ \\
\hline X32 & CM_long & $\leftarrow$ & $\mathrm{CM}$ & & $0.655^{*}$ \\
\hline X33 & CM_strat & $\leftarrow$ & $\mathrm{CM}$ & & $0.693^{*}$ \\
\hline X34 & CM_waste & $\leftarrow$ & $\mathrm{CM}$ & & $0.727 *$ \\
\hline X35 & CM_new & $\leftarrow$ & $\mathrm{CM}$ & & $0.718^{*}$ \\
\hline X36 & CM_first & $\leftarrow$ & $\mathrm{CM}$ & & $0.605^{*}$ \\
\hline $\mathrm{X} 41$ & PA_quant & $\leftarrow$ & PA & & $0.918^{*}$ \\
\hline $\mathrm{X} 42$ & PA_qual & $\leftarrow$ & $\mathrm{PA}$ & & $0.851^{*}$ \\
\hline $\mathrm{X} 43$ & PA_smat & $\leftarrow$ & $\mathrm{PA}$ & & $0.651^{*}$ \\
\hline X44 & PA_targets & $\leftarrow$ & $\mathrm{PA}$ & & $0.638^{*}$ \\
\hline
\end{tabular}

$* p<0.001$

t-values 8.144 to 24.104

Table 8. Goodness of fit indices for the structural model

\begin{tabular}{|l|c|c|}
\hline \multicolumn{1}{|c|}{$\begin{array}{c}\text { Goodness of fit } \\
\text { measures }\end{array}$} & $\begin{array}{c}\text { Recommended } \\
\text { Values }\end{array}$ & Results \\
\hline$\chi^{2} / \mathrm{df}$ & $\leq 3.00$ & 1.874 \\
\hline GFI & $\geq 0.90$ & 0.940 \\
\hline AGFI & $\geq 0.85$ & 0.923 \\
\hline CFI & $\geq 0.95$ & 0.964 \\
\hline NFI & $\geq 0.90$ & 0.927 \\
\hline SRMR & $\leq 0.10$ & 0.046 \\
\hline RMSEA & $\leq 0.08$ & 0.041 \\
\hline
\end{tabular}


Table 9: Structural mediating model via OPS_PERF - regression weights

\begin{tabular}{|lll|c|c|c|}
\hline & & & $\boldsymbol{\beta}$ & S.E. & t-values \\
\hline SMC & $\rightarrow$ & OPS_PERF & $0.334^{*}$ & 0.058 & 5.807 \\
\hline OPS_PERF & $\rightarrow$ & FIN_OPS & $0.876^{*}$ & 0.126 & 6.953 \\
\hline SMC & $\rightarrow$ & FIN_PERF & $-0.034^{* *}$ & 0.065 & -0.516 \\
\hline
\end{tabular}

$* p<0.001 ; * * N S$ 


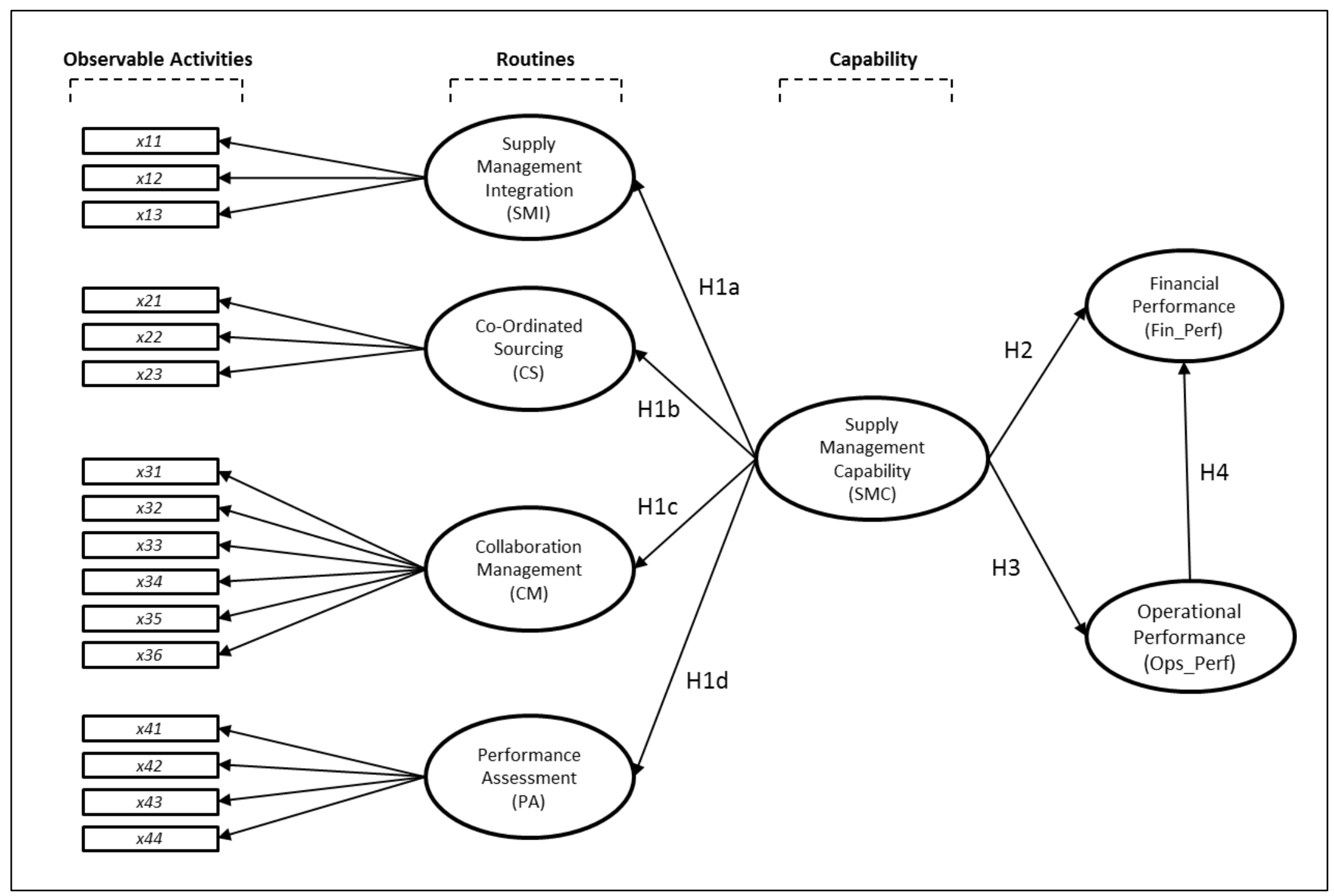


Fig. 2: Structural mediation model

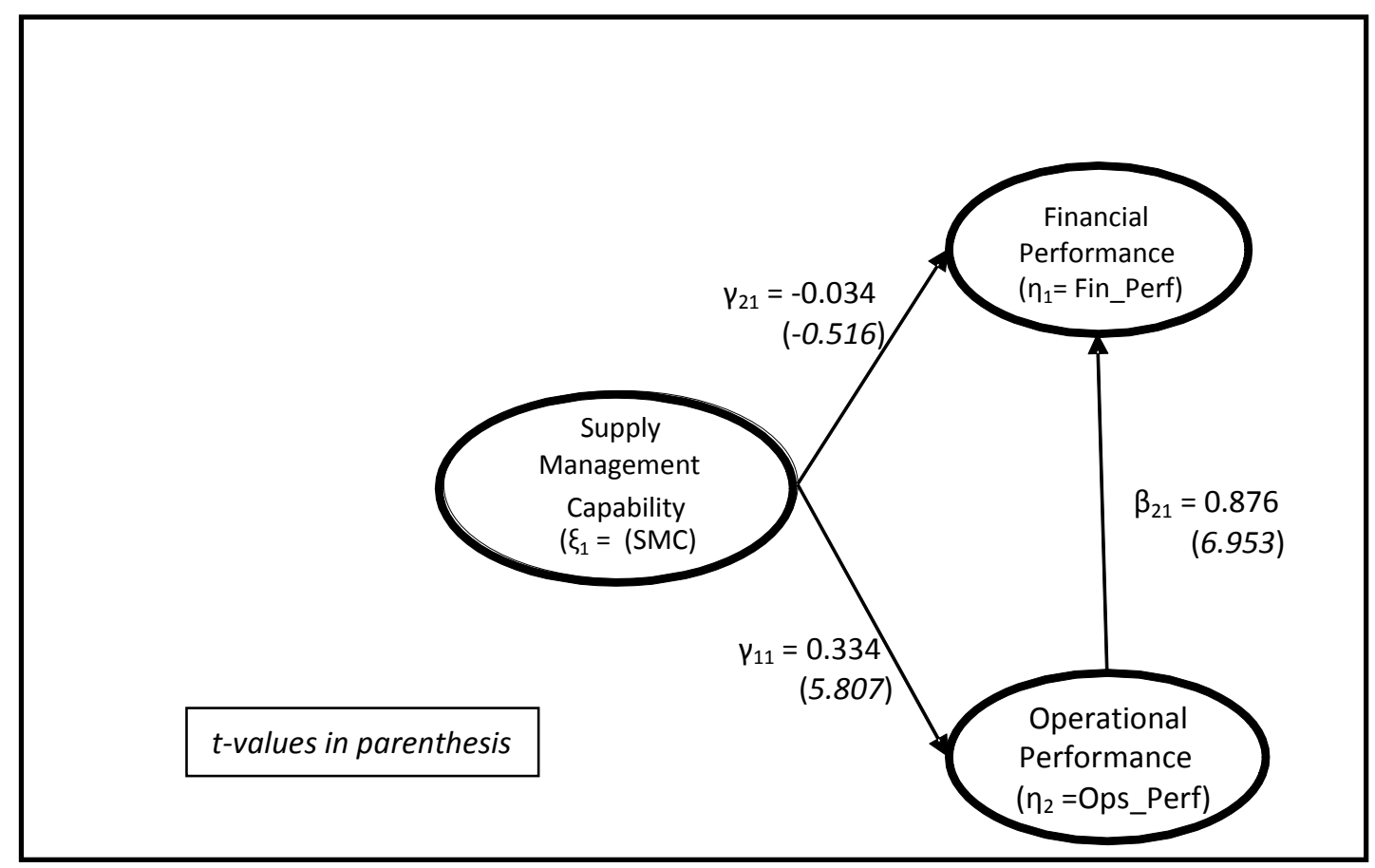


SMI - Supply management integration

Statements relating to current processes reflecting the status of supply management at the firm. Respondents select a rating for their current perception of each process from a five-point scale. Likert scale 1: strongly disagree, 3: neither agree nor disagree, 5: strongly agree

X11 Those with supply management responsibility regularly attend company strategy meetings. (SMI_attend)

X12 Supply managers influence all expenditure with suppliers. (SMI_influence)

X13 Those with supply management skills are involved in important make versus buy decisions. (SMI_makebuy)

\section{CS-Coordinated sourcing}

Statements relating to current processes which support strategic supply management at the firm. Respondents select a rating for their current perception of each process from a five-point scale. Likert scale 1: strongly disagree, 3: neither agree nor disagree, 5: strongly agree

X21 Common products and services are purchased in a co-ordinated manner across our business. (CS_comm)

X22 Our company has a clear understanding of its total expenditure with suppliers. (CS_total)

X23 We have effective business processes that control the cost of inputs from suppliers. (CS effect)

\section{CM-Collaboration management}

Statements relating to current processes for the ongoing management of supplier relationships. Respondents select a rating for their current perception of each process from a five-point scale. Likert scale 1: strongly disagree, 3: neither agree nor disagree, 5: strongly agree

We engage in structured joint problem solving with suppliers (CM_joint)

We foster long-term joint development relationships with certain suppliers. (CM_long)

We have a strategic plan for the structure of our supply base (CM_strat)

My company works with suppliers to drive out waste in supply chain processes. (CM_waste)

Our supply manangers jointly identify innovations with suppliers for new products/services (CM_new)

I feel confident that suppliers bring new ideas to our company before offering them to others. (CM first)

\section{$P A$ - Performance assessment}

Statements relating to current processes to assess and control supply management performance. Respondents select a rating for their current perception of each process from a five-point scale.

Likert scale 1: strongly disagree, 3: neither agree nor disagree, 5: strongly agree

X41 We use quantitative measures of supplier performance. (PA_quan)

X42 We use qualitative measures of supplier performance. (PA_qual)

X43 The metrics we use to measure internal supply management performance are SMART. (specific, measurable, achievable, realistic, time-related) (PA_smat)

All those with re rensibility for suppliers have individual perormance are SMART. (specific, measurable, achieva

\section{Current company performance}

To the best of your knowledge, please indicate how your company has performed in comparison to its competitors in the LAST THREE YEARS on the following measures. Five-point scale anchored between 1: much worse and 5: much better.

The overall performance of the company (Pfin_overall)

The return on investment in the company (Pfin_roi)

Growth in the volume of sales (Pfin vol)

Research and development (e.g., ratio of research and development to total sales) (Pops_RD)

Cost reduction (e.g., ratio of costs of goods sold to sales revenue) (Pops_Cost)

Number of joint company/supplier innovations implemented (Pops_innov)

Market focus (e o, ratio of marketing expenditure to total sales) (Pops_mkt) 


\section{References}

Allred, C.R., Fawcett, S.E., Wallin, C., Magnan, G.M., 2011. A dynamic collaboration capability as a source of competitive advantage. Decision Science 42 (1), 129-161.

Amit, R., Schoemaker, P.J.H, 1993. Strategic assets and organisational rent. Strategic Management Journal 14 (1), 33-46.

Anderson, J.C., Gerbing, D.W., 1988. Structural equation modeling in practice: a review and recommended two-step approach. Psychological Bulletin 103 (3), 411-423.

Aoki, M., 1988. Information, Incentives, and Bargaining in the Japanese Economy. Cambridge University Press, New York.

Arbuckle, J. L., Wothke, W., 1999. AMOS 4.0 user's guide. Smallwaters, Chicago.

Armstrong, J.S., Overton, T.S., 1977. Estimating nonresponse bias in mail surveys. Journal of Marketing Research 14 (August), 396-402.

Asanuma B., (1989), "Manufacturer-Supply Relationships in Japan and the Concept of RelationSpecific Skill", Journal of the Japanese and International Economies, 3, pp. 1-30.

Baier, C., Hartmann, E., Moser, R., 2008. Strategic alignment and purchasing efficacy: An exploratory analysis of their impact on financial performance. Journal of Supply Chain Management 44 (4), 36-52.

Baron, R.M., Kenny, D.A., 1986. The moderator-mediator variable distinction in social psychological research: Conceptual, strategic, and statistical considerations. Journal of Personality and Social Psychology 51 (6), 1173-1182.

Betsch, T., Haberstroh, S., Glöckner, A., Haar, T., Fiedler, K., 2001. The effects of routine strength on adaptation and information search in recurrent decision making. Organisation Behaviour \& Human Decision Processes 84 (1), 23-53.

Blois, K. J., 1972, Vertical quasi-integration, Journal of Industrial Economics, XX (3), 253-272.

Byrne, B.M., 2001. Structural equation modeling with AMOS. Lawrence Erlbaum Associates, Mahwah, NJ.

Cao, M., Zhang, Q., 2010. Supply chain collaboration: Impact on collaborative advantage and firm performance. Journal of Operations Management 29 (3), 163-180.

Carr, A. S., Pearson, J.N., 1999. Strategically managed buyer-supplier relationships and performance outcomes. Journal of Operations Management 17 (5), 497-519.

Carr, A.S., Pearson, J.N., 2002. The impact of purchasing and supplier involvement on strategic purchasing and its impact on firm's performance. International Journal of Operations \& Production Management 22 (9), 1032-1053. 
Carr, A.S., Smeltzer, L.R., 1997. An empirically based operational definition of strategic purchasing. European Journal of Purchasing \& Supply Management 3 (4), 199-207.

Carr, A. S., Smeltzer, L. R., 2000 An empirical study of the relationships among purchasing skills and strategic purchasing, financial performance, and supplier responsiveness. Journal of Supply Chain Management 36, 40-54.

Chen, I.J., Paulraj, A., Lado, A.A., 2004. Strategic purchasing, supply management, and firm performance. Journal of Operations Management 22 (5), 505-523.

Chin, W.W., 1998. The partial least squares approach to structural equation modeling, in:

Marcoulides, G. A. (Ed.), Modern Methods for Business Research. Lawrence Erlbaum Associates, London.

Choi, T.Y., Hartley, J.L., 1996. An exploration of supplier selection practices across the supply chain. Journal of Operations Management 14 (4), 333-343.

Chou, C-P., Bentler, P. M., 1995. Estimates and tests in structural equation modeling. In R. H. Hoyle (Ed.), Structural Equation Modeling: Concepts, Issues and Applications 1995 (pp. 37-55). Thousand Oaks, Sage, CA.

Churchill, G., 1979. A paradigm for developing better measures of marketing constructs. Journal of Marketing Research, 16(February), 64-73.

Cohen, M. D., 2007. Reading Dewey: Reflections on the study of routine. Organization Science, 28 (5), 773-786.

Colombo, M.G., Mariotti, S., 1998.Organizing vertical markets: the Italtel case. European Journal of Purchasing and Supply Management 4 (1), 7-19.

Cousins, P D., 2005. The alignment of appropriate firm and supply strategies for competitive advantage. International Journal of Operations and Production Management 25 (5) $403-428$

Das, A., Narasimhan, R., 2000. Purchasing competence and its relationship with manufacturing performance. Journal of Supply Chain Management 36 (2), 17-28.

Das, A., Narasimhan, R., Talluri, S., 2006. Supplier integration - finding an optimal configuration. Journal of Operations Management 24 (5), 563-582.

Dess, G., Robinson Jr., R., 1984. Measuring organisational performance in the absence of objective measures: The case of privately-held firm and conglomerate business unit. Strategic Management Journal 5, 265-273.

Dillman, D.A., 2007. Mail and Internet Surveys: The Tailored Design Method, second ed. John Wiley \& Sons, Hoboken, NJ.

Drnevich, P.L., Kriauciunas, A.P., 2011. Clarifying the conditions and limits of the contributions of ordinary and dynamic capabilities to relative firm performance. Strategic Management Journal 32 (3), 254-279. 
Dyer, J.H., 1997. Effective interfirm collaboration: How firms minimize transaction costs and maximize transaction value. Strategic Management Journal 18 (3), 535-556.

Ellram, L.M., 2006. The implementation of target costing in the United States: Theory versus practice. Journal of Supply Chain Management 42 (1), 13-26.

Ellram, L. M., Carr, A., 1994. Strategic purchasing: A history and review of the literature. International Journal of Purchasing and Materials Management 30 (2), 10-18.

Ellram, L.M., Liu, B., 2002. The financial impact of supply management. Supply Chain Management Review 6 (6), 30-36.

Ellram, L.M., Zsidisin, G.A., Siferd, S.P., Stanly, M. J., 2002. The impact of purchasing and supply management activities on corporate success. Journal of Supply Chain Management 38 (1), 4-17.

Esposito, E., Raffa, M., 1994. The evolution of Italian subcontracting firms: empirical evidence. European Journal of Purchasing and Supply Management 1 (2), 67-76

Feldman, B. T., Pentland, B., 2003. Reconceptualizing organizational routines as a source of flexibility and change. Administrative Science Quarterly 48 (1), 94-118.

Felin, T., Foss, N. J., Hemericks, K. H., Madsen, T. L., 2012, Microfoundations of routines and capabilities: Individuals, processes and structure, Journal of Management Studies 49(8), 1351-1374.

Fornell, C., Larcker, D.F., 1981. Evaluating structural equation models with unobservable variables and measurement error. Journal of Marketing Research 18 (1), 39-50.

Frohlich, M.T., Westbrook, R., 2001. Arcs of integration: An international study of supply chain strategies. Journal of Operations Management 19 (2), 185-200.

González-Benito, J., 2007. A theory of purchasing's contribution to business performance. Journal of Operations Management 25 (4), 901-917.

Götz, O., Liehr-Gobbers, K., Krafft M., 2009. Evaluation of structural equation models using the partial least squares (PLS) approach, in: Esposito, V., Chin, W. W., Henseler, J., Wang, H. (Eds.), Handbook of Partial Least Squares: Concepts, Methods and Applications. Springer, Berlin.

Grant, R.M., 1996. Toward a knowledge-based theory of the firm. Strategic Management Journal $17,109-122$.

Hair, J.F., Black, W.C., Babin, B.J., Anderson, R.E., 2010. Multivariate Data Analysis. Pearson Prentice Hall, New Jersey.

Hart, S., Banbury, C., 1994. How strategy-making processes can make a difference. Strategic Management Journal 15 (4), 251-269.

Hartmann, E., Kerkfeld, D., Henke, M., 2012. Top and bottom line relevance of purchasing and supply management, Journal of Purchasing and Supply Manageemnt 18(1), 22-34. 
Heide, J.B. and Miner, A.S. 1992. The shadow of the future: effects of anticipated interaction and frequency of contact on buyer-seller cooperation. Academy of Management Journal, 35(2), 265-291

Helfat, C.E., Peteraf, M.A., 2003. The dynamic resource-based view: Capability lifecycles. Strategic Management Journal 24 (10), 997-1010.

Helfat, C.E., Winter, S.G., 2011. Untangling dynamic and operational capabilities: Strategy for the (n)ever-changing world. Strategic Management Journal 32 (11), 1243-1250.

Holmbeck, G.N., 1997. Toward terminological, conceptual, and statistical clarity in the study of mediators and moderators: Examples from the child-clinical and paediatric psychology literatures. Journal of Consulting and Clinical Psychology 65 (4), 599-610.

Hoyle, R. H., (Ed.), (1995). Structural equation modeling: Concepts, issues and application. Thousand Oaks, Sage, CA.

Hoyle R. H., Panter, A. T., 1995. Writing about structural equation models. In R. H. Hoyle (Ed.), Structural equation modeling: Concepts, issues and applications 1995 (pp. 37-55). Thousand Oaks, Sage, CA.

Hu, L., Bentler, P.M., Kano, Y., 1992. Can test statistics in covariance structure analysis be trusted? Psychological Bulletin 112 (2), 351-362.

Hult, G.T M., Ketchen Jr., D.J., Nichols Jr., E.L., 2003. Organisational learning as a strategic resource in supply management. Journal of Operations Management 21 (5), 541-556.

Kaleka, A., 2002. Resources and capabilities driving competitive advantage in export markets: Guidelines for industrial exporters. Industrial Marketing Managment 31 (3), 273-283.

Kannan, V. R., Tan, K. C., 2006. Buyer-supplier relationships: The impact of supplier selection and buyer-supplier engagement on relationship and firm performance, International Journal of Physical Distribution and Logistics Management 36 (10), 755-775.

Klassen, R.D., Whybark, D.C., 1999. The impact of environmental technologies on manufacturing performance. Academy of Management Journal 42 (6), 599-615.

Klein, B., Crawford, R.,Alchian,A.,1978. Vertical integration, appropriable rents and the competitive contracting process. The Journal of Law and Economics 21 (2), 297-326.

Krause, D.R., Handfield, R. B., Scannell, T. V., 1998. An empirical investigation of supplier development: Reactive and strategic processes. Journal of Operations Management 17 (1), 39-58.

Krause, D. R., Handfield, R.B., Tyler, B.B., 2007. The relationships between supplier development, commitment, social capital accumulation and performance improvement. Journal of Operations Management 25 (2), 528-545.

Krause, D.R., Pagell, M., Curkovic, S., 2001. Toward a measure of competitive priorities for purchasing. Journal of Operations Management 19 (4), 497-512. 
Liao, S-H., Kuo, F-L., 2014. The study of relationships between the collaboration for supply chain, supply chain capabilities and firm performance: A case of the Taiwan's TFT-LCD industry. International Journal of Production Economics 156, 295-304.

Lawson, B., Cousins, P.D., Handfield, R.B., Petersen, K.J., 2009. Strategic purchasing, supply management practices and buyer performance improvement: An empirical study of UK manufacturing organisations. International Journal of Production Research 47 (10), 2649-2667.

Lawson, B., Tyler, B.B., Cousins, P.D., 2008. Antecedents and consequences of social capital on buyer performance improvement. Journal of Operations Management 26 (3), 446-460.

Mahapatra, S.K., Narasimhan, R., Barbieri, P., 2010. Strategic interdependence, governance effectiveness and supplier performance: A dyadic case study investigation and theory development. Journal of Operations Management 28 (6), 537-552.

Marsh, H.W., Hocevar, D., 1985. Application of confirmatory factor analysis to the study of selfconcept: first and higher order factor models and their invariance across groups. Psychological Bulletin 97 (3), 562-582.

McIvor, R., 2009. How the transaction cost and resource-based theories of the firm inform outsourcing evaluation. Journal of Operations Management 27 (1), 45-63.

Narasimhan, R., Das, A., 2001. The impact of purchasing integration and practices on manufacturing performance. Journal of Operations Management 19 (5), 593-609.

Narasimhan, R., Jayaram, J., Carter, J.R., 2001. An empirical examination of the underlying dimensions of purchasing competence. Production and Operations Management 10 (1), 1-15.

Nelson, R.R., Winter, S.G., 1982. An Evolutionary Theory of Economic Change. Bellknap Press, Cambridge, MA.

Nollet, J., Calvi, R., Audet, E. Côté, M. 2008. When excessive cost savings measurement drowns the objectives. Journal of Purchasing and Supply Management 14 (1): 125-135.

Noordewier, T. G., John, G., Nevin, J. R., 1990. Performance outcomes of purchasing arrangements in industrial buyer-vendor relationships. Journal of Marketing 54 (4), 80-93.

Olinsky, A., Chen, S., Harlow, L., 2003. The comparative efficacy of imputation methods for missing data in structural equation modeling. European Journal of Operations Research 151 (1), 5379.

Olsson, U.H., Foss, T., Troye, S.V., Howell, R.D., 2000. The performance of ML, GLS, and WLS estimation in structural equation modeling under conditions of misspecification and nonnormality. Structural Equation Modelling 7 (4), 557-595.

Parmigiani, A., Howard-Grenville, J., 2011. Routines revisited: Exploring the capabilities and practices perspectives. Academy of Management Annals 5(1), 413-453.

Paulraj, A., Chen, I.J., Flynn, J., 2006. Levels of strategic purchasing: Impact on supply integration and performance. Journal of Purchasing and Supply Management 12 (3), 107-122. 
Paulraj, A., Lado, A.A., Chen, I.J., 2008. Inter-organisational communication as a relational competency: Antecedents and performance outcomes in collaborative buyer-supplier relationships. Journal of Operations Management 26 (1), 45-64.

Pearce II, J.A., Robbins, D.K., Robinson Jr, R.B., 1987. The impact of grand strategy and planning formality on financial performance. Strategic Management Journal 8 (2), 125-134.

Peng, D., Schroeder, R., Shah, R., 2008. Linking routines to operations capabilities: A new perspective. Journal of Operations Management 26 (6), 730-748.

Peng, M.W., York, A. S., 2001. Behind intermediary performance in export trade: Transactions, agents, and resources. Journal of International Business Studies 32 (2), 327-346.

Pentland, B. T., Feldman, M. S., 2005. Organizational routines as a unit of analyis. Industrial and Corporate Change 14 (5), 793-815.

Pentland, B. T., Reuter, H. H., 1994, Organizational routines as grammars of action, Administrative Science Quarterly, 39, 484-510.

Petersen, K.J., Handfield, R.B., Ragatz, G.L., 2005. Supplier integration into new product development: Coordinating product, process and supply chain design. Journal of Operations Management 23 (3/4), 371-388.

Podsakoff, P.M., MacKenzie, S.B., Lee, J-Y, Podsakoff, N.P.., 2003. Common method biases in behavioural research: A critical review of the literature and recommended remedies. Journal of Applied Psychology 88 (5), 879-903.

Podsakoff, P.M., Organ, D.W., 1986. Self-reports in organisational research: Problems and prospects. Journal of Management 12 (4), 531-544.

Pohl, M., Förstl, K., 2011. Achieving purchasing competence through purchasing performance measurement system design - a multiple-case study analysis. Journal of Purchasing and Supply Management 17, 231-245.

Reuter, C., Foerstl, K., Hartmann, E., Blome, C., 2010. Sustainable global supplier management: The role of dynamic capabilities in achieving competitive advantage. Journal of Supply Chain Management 46 (2), 45-63.

Rindskopf, D., Rose, T., 1988. Some theory and applications of confirmatory second-order factor analysis. Multivariate Behavioral Research, 23, 51-67.

Rozemeijer, F. A., 2008, Purchasing myopis revisited again? Journal of Purchasing and Supply Management, 14 (3), 205-207.

Sako, M., 1992. Quality and Trust: Inter-firm Relations in Britain \& Japan. Cambridge University Press, Cambridge.

Salvato, C., Rerup, C., 2011. Beyond collective entities: Multilevel research on organisational routines and capabilities. Journal of Management 37 (2), 468-490. 
Schermelleh-Engel, K., Moosbrugger, H., Müller, H., 2003. Evaluating the fit of structural equation models: tests of significance and descriptive goodness-of-fit measures. Methods in Psychological Research Online 8 (2), 23-74.

Schiele, H., 2007. Supply management maturity, cost savings and purchasing absorbtive capacity: Testing the procurement-performance link, Journal of Purchasing and Supply Management 13 (2), 274-293.

Segars, A.H., Grover, V., 1998. Strategic information systems planning success: an investigation of the construct and its measurement. MIS Quarterly 22 (2), 139-163.

Singhal, V.R., Hendricks, K.B., 2002. How supply chain glitches torpedo shareholder value. Supply Chain Management Review 6 (1), 18-24.

Smeltzer, L.R., Manship, J.A., Rossetti, C.L., 2003. An analysis of the integration of strategic sourcing and negotiation planning. Journal of Supply Chain Management 39 (4), 16-25.

Sobel, M.E., 1982. Asymptotic intervals for indirect effects in structural equations models. In S. Leinhart (Ed.), Sociological methodology. Jossey-Bass, San Francisco.

Spekman, R.E., Kamauff, J., Spear, J., 1999. Towards more effective sourcing and supplier management. European Journal of Purchasing \& Supply Management 5 (2), 103-116.

Squire, B., Cousins, P., Brown, S., 2009. Cooperation and Knowledge Transfer within BuyerSupplier Relationships: The Moderating Properties of Trust, Relationship Duration and Supplier Performance. British Journal of Management 20(4), 461-477.

Takeishi, A., 2001. Bridging inter- and intra-firm boundaries: Management of supplier involvement in automobile product development. Strategic Management Journal 22 (5), 403-433.

Tan, K. C., Handfild, R. B., Krause, D. R. 1998, Enhancing the firm's performance through quality and supply base management: An empirical study, International Journal of Production Research, 36 (10), 2813-2837.

Teece, D.J., Pisano, G., Shuen, A., 1997. Dynamic capabilities and strategic management. Strategic Management Journal 18 (7), 509-533.

Thomas, A., Ramaswamy, K., 1996. Matching managers to strategy: further tests of the Miles and Snow typology. British Journal of Management 7 (3), 247-261.

Tracey, M., Lim, J-S., Vonderembse, M. A., 2005. The impact of supply chain management capabilities on business performance. Supply Chain Management 10(3/4), 179-191.

Venkatraman, N., Grant, J.H., 1986. Construct measurement in organisational strategy research: A critique and proposal. Academy of Management Review 11, 71-87.

Venkatraman, N., Ramanujam, V., 1986. Measurement of business performance in strategy research: A comparison of approaches. Academy of Management Review 11 (4), 801-814. 
Vickery, S.K., 1991. A theory of production competence revisited. Decision Sciences 22 (3), 635643.

Wagner, S.M., Johnson, J.L., 2004. Configuring and managing strategic supplier portfolios. Industrial Marketing Management 33 (8), 717-730.

Wernerfelt, B., 1984. A resource-based view of the firm. Strategic Management Journal 5 (2), 171180.

Winter, S.G., 2003. Understanding dynamic capabilities. Strategic Management Journal. 24 (10), 991-995.

Yeung, A., 2008. Strategic supply management, quality initiatives, and organisational performance. Journal of Operations Management 26 (4), 490-502.

Youndt, M.A., Snell, S.A., Dean Jr., J.W., Lepack, D.P., 1996. Human resource management, manufacturing strategy, and firm performance. Academy of Management Journal 39 (4), 836-866.

Zahra, S.A., Sapienza, H.J., Davidsson, P. (2006) Entrepreneurship and dynamic capabilities: A review, model and research agenda. Journal of Management Studies 43 (4), 917-955.

Zott, C., 2003. Dynamic capabilities and the emergence of intraindustry differential firm performance: Insights from a simulation study. Strategic Management Journal 24 (2), 97-125.

Zsidisin, G.A., Ellram, L.M., 2001. Activities related to purchasing and supply management involvement in supplier alliances. Interationa Journal of Physical Distribution \& Logistics Management 31 (9/10), -6617-635. 